\title{
Maternal care in the preterm child's family context: A comprehensive look towards the sibling
}

\author{
Cuidado materno no contexto familiar do prematuro: olhar integral voltado ao irmão
}

Cuidado materno en el contexto familiar del prematuro: una mirada integral hacia el hermano

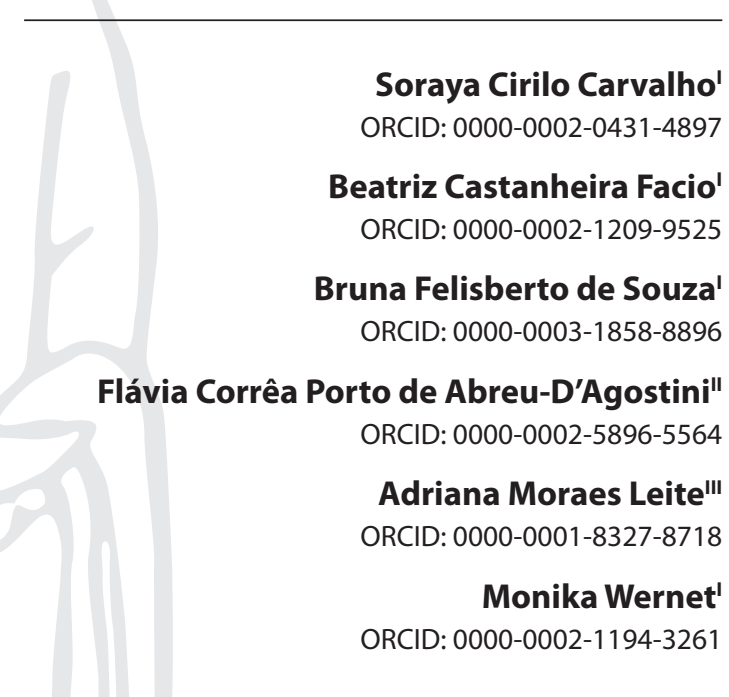

'Universidade Federal de São Carlos. São Carlos, São Paulo, Brazil. "Universidade de São Paulo. São Paulo, São Paulo, Brazil. I" Universidade de São Paulo. Ribeirão Preto, São Paulo, Brazil.

How to cite this article:

Carvalho SC, Facio BC, Souza BF, Abreu-D'Agostini FCP, Leite AM, Wernet M. Maternal care in the preterm child's family context: A comprehensive look towards the sibling. Rev Bras Enferm. 2019;72(Suppl 3):50-7. doi: http://dx.doi.org/10.1590/0034-7167-2017-0780

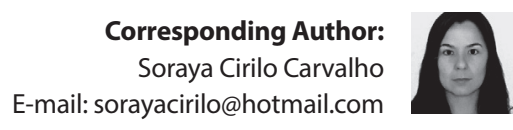

Submission: 11-01-2017 Approval: 05-30-2018

\begin{abstract}
Objective: To analyze maternal care for siblings of preterm babies hospitalized in the neonatal intensive care unit. Method: Qualitative research using symbolic interactionism as a theoretical reference and narrative research as a methodological reference. Ten mothers were surveyed through semi-structured interviews. Results: Three thematic units emerged from the analysis of data: "social support in the sharing of child care"; "promotion of adaptation to the arrival of a sibling" and "maternal feelings and coping". Final considerations: Care for the premature child's sibling is developed under mothers' physical distance from him/her, justified by the need to remain close to the premature child due to risks and fragility related to the condition.

Descriptors: Infant, Premature; Child Care; Intensive Care Units, Neonatal; Mother-Child Relations; Maternal Behavior.
\end{abstract}

\section{RESUMO}

Objetivo: analisar o cuidado materno ao irmão da criança nascida pré-termo hospitalizada na Unidade de Terapia Intensiva neonatal. Método: pesquisa qualitativa, que elencou o interacionismo simbólico como referencial teórico e a pesquisa de narrativa como referencial metodológico. Dez mães foram submetidas a entrevistas semiestruturadas. Resultados: da análise de dados, emergiram três unidades temáticas: "apoio social na partilha do cuidado do filho"; "promoção da adaptação à chegada do irmão" e "sentimentos e enfrentamento materno". Considerações finais: o cuidado ao irmão da criança nascida pré-termo é desenvolvido sob um afastamento físico das mães perante ele, justificado pela necessidade dessa de se manter próxima ao filho nascido pré-termo em função dos riscos e da fragilidade relativos à condição.

Descritores: Recém-Nascido Prematuro; Cuidado da Criança; Unidades de Terapia Intensiva Neonatal; Relações Mãe-Filho; Comportamento Materno.

\section{RESUMEN}

Objetivo: analizar el cuidado materno al hermano del niño nacido pretérmino hospitalizado en una Unidad de Cuidados Intensivos Neonatal. Método: investigación cualitativa, que utilizó el interacionismo simbólico como marco teórico y la investigación de narrativa como marco metodológico. Se aplicaron entrevistas semiestructuradas a diez madres. Resultados: del análisis de datos surgieron tres ejes temáticos: "Apoyo social en el reparto del cuidado del hijo"; "Estímulo para adaptar la llegada del hermano" y "Sentimientos y enfrentamiento materno". Consideraciones finales: el cuidado del hermano del niño nacido pretérmino se desarrolla ante un alejamiento físico de las madres, con la justificación de que es necesario mantenerse cercana al hijo nacido pretérmino en función de los riesgos y de la fragilidad relativos a su condición.

Descriptores: Recién Nacido Prematuro; Cuidado del Niño; Unidades de Cuidado Intensivo Neonatal; Relaciones Madre-Hijo; Conducta Materna. 


\section{INTRODUCTION}

The arrival of a new baby is one of the most critical phases in terms of developments for the family life cycle, bringing repercussions to family members' relationships ${ }^{(1)}$, with consequent adaptations and restructuring that are shaped according to the new roles taken ${ }^{(2)}$. Such reality can be accentuated as a result of a premature birth, which, because of its unpredictability, affects all family members and ongoing processes, including that of becoming a sibling ${ }^{(3)}$.

According to Ministry of Health data for 2012, 11.8\% of live births in Brazil were preterm, $40.8 \%$ of whom born in the Southeast region ${ }^{(4)}$. In these cases, due to the immaturity of the organic systems, there is sometimes a need for differentiated care and hospitalization in Neonatal Intensive Care Units (NICU) ${ }^{(3)}$.

Health professionals in this setting, especially nursing, should seek to meet the needs of newborns' parents and family members, and this includes sibling(s), who often need support to continue their daily routines due to the new feelings caused by the arrival of a (premature) baby in the family and consequent hospitalization $^{(5)}$. Accordingly, the Brazilian ministerial recommendation of humanized care in the neonatal context ${ }^{(6)}$ establishes the presence and participation of the extended family as fundamental elements in supporting the infant and parents during hospitalization, as well as recommending that visits to neonatal units should be allowed, either with free access or at established times, including grandparents and siblings.

Accordingly, understanding aspects that permeate the experience of a preterm baby's sibling is important and little explored in the health literature ${ }^{(7)}$. This study contributes specifically to the research question: how does the mother care for the sibling of a baby born preterm and hospitalized in the NICU?

\section{OBJECTIVE}

To analyze maternal care for the sibling of the preterm born infant hospitalized in NICU.

\section{METHOD}

\section{Ethical aspects}

This research was approved by the Ethics Committee of Research with Human Beings of the Federal University of São Carlos, São Carlos campus, SP. All participants signed the Free and Informed Consent Form. In order to protect participants'identity, narratives excerpts were identified with the word "mother" followed by Arabic number indicating the order of insertion in the study. To facilitate reading and understanding, the child who is the premature's sibling will be called "sibling" and the preterm child will be referred to as "premature".

\section{Type of study and theoretical reference}

As the object of study is maternal care given to the sibling of the hospitalized preterm infant, the qualitative approach emerged as adequate. This was due to the appreciation that such an approach brought to the universe of meanings, aspirations, beliefs, values and attitudes of social subjects, with a view to understanding subjects' daily experiences, highlighting the importance of the content of information in deepening the subjectivity of the meanings of human actions and relations ${ }^{(8)}$. Thus, the selection of symbolic interactionism (SI) as a theoretical reference has become pertinent, since such an approach focuses on human actions, with attention to how meanings occur and are sustained in social interactions ${ }^{(9)}$. It was argued, therefore, that maternal care is dependent on the meaning ascribed to such social objects as prematurity, NICU, fraternity, family, parental care, among others.

\section{Methodological procedures}

First, a survey of possible participants of the study in the NICU of a teaching hospital of a city in the interior of the state of Minas Gerais (MG) was carried out from January to May 2014. The selection criteria were: being mother of a child born with gestational age between 24 and 34 weeks (moderate and extreme preterm), with immediate need for hospitalization in a NICU; having two (or more) biological children, one of whom in early childhood (0-6 years, i.e., with less autonomy for self-care); aged 18 years or older, or being legally emancipated. Fifteen potential participants were identified, who were personally contacted by the unit's nurse in order to get in touch with the researcher. In this contact, the nurse checked the mother's interest in taking part in the study, and if so scheduled a face-to-face conversation between her and the researcher, when the researcher would explain the study and verify her interest in participating. A new meeting was then scheduled for the interview. Of the 15 potential participants, 10 took part in the study. Refusals were justified by non-availability due to emotional fragility. We point out that of the 10 participants, two contributed for validation of the results obtained.

It should be emphasized that the empirical material presented here was articulated with the temporal design given to the study, and that the primary data obtained presented density, repetition and complementarity in terms of conceptual elements, a fact that allowed the analysis of the phenomenon in focus.

\section{Study scenario}

This study was conducted in a municipality in the Triângulo Mineiro microregion in the state of Minas Gerais, with an estimated population of 325,279 residents over an area of 4,523,957 square $\mathrm{km}^{(10)}$. The rate of live births in 2015 was 5,682, of which $818(14.39 \%)$ were preterm ${ }^{(4)}$.

Child health care in the city is carried out from two NICUs, one private and one public. The public NICU, this study's setting, has 20 beds and provides care to a wide region, covering the 27 municipalities that make up the triângulo sul macroregion. This is the only public hospital that provides outsourced service of high complexity.

\section{Collection and organization of data}

Data collection took place in a private environment provided by the institution between May and December 2014, during hospitalization of the premature child at NICU, through semi-structured interviews triggered by the question: "Tell me how you are doing 
with (name of sibling) while (premature) is hospitalized here." After the question, other issues would be addressed to further explore the phenomenon. All interviews were conducted in a single meeting and only by the first author of the study, with a mean duration of 33 minutes. A digital audio device was used to record the interviews to facilitate getting the narrative and to avoid loss of significant data. Subsequently, they were fully transcribed.

\section{Data analysis}

The data were analyzed in the light of the methodological reference of narrative research, in the holistic perspective with emphasis on content, by following four steps: reiterative reading of the collected material in empathetic manner, to establish a central nucleus, focus of story as a whole; note of early global impressions; specification of the terms or foci of content to be followed in the reconstruction of the story; and, finally, the analytical process, with resumption of the reflective reading of the story, highlighting narrated excerpts that depict specified themes ${ }^{(11)}$. In extracting, analyzing and understanding the stories experienced in intersubjective interactional contexts, this framework contributes to a reflection on stories and portrays the meanings ascribed by subjects to their own experiences in the I-world relationship ${ }^{(12)}$. The research team and authors of this article engaged in the transcription of interviews and discussions of the analytical process developed in dyad by the first and last authors. In addition, the entire team contributed to the discussions and final considerations.

\section{RESULTS}

Ten mothers of preterm infants were interviewed, eight during the development of the master's degree and two afterwards, for validation. Participants were between 18 and 29 years old, four were married, two lived in cohabitation, two were in a stable relationship and two were single. As for schooling, five mothers had completed high school, two had completed elementary education, one had incomplete elementary school and two had incomplete high school. The mean gestational age was 32 weeks and three days. With regard to preterm infant's days of life, it ranged from 6 to 22 days. Seven were mothers to only one child other than the preterm infant and one was mother to two other children. The age of the other children ranged from 1 to 6 years. The ages of the only case of two children other than the preterm child were 4 and 6 years.

From the analysis of narratives it was possible to identify three thematic units that characterize maternal care of the preterm infant's sibling, namely: "social support in the sharing of child care"; "promotion of adaptation to the arrival of the sibling" and "maternal feelings and coping".

\section{Thematic unit: social support in the sharing of child care}

This unit deals with the maternal action of providing care and well-being to the sibling. In this sense, a first move is to list the mother's and sibling's priority needs, as well as to identify means to guarantee their supply, considering the particularity of the Mother's"presence" beside him/her.
The quest to ensure the sibling's well-being articulates directly with the process of choosing the person who will take care of him/ her in the absence of the mother. For this, mothers turn to people in their social environment and appreciate them in thought. In addition, they program their presence in the NICU according to their social network's availability to provide care for their children.

So the two [children] go to school, they stay in daycare. Then in the afternoon they stay in school. Then they arrive by van, and my mother stays with them until I arrive. (Mother 4)

[Daughter's name] stays with my mother, usually when my mother comes with me here to NICU she stays with my sister, who lives on the same street. (Mother 8)

I think she's staying with my sister. She was the only person I found by now. It was the only person I could find to stay with her so I could come here. (Mother 5)

Still on the choice of caregiver, it was possible to identify that women resort, mostly, to their own relatives, especially their mother and/or sister. In their choices, they ponder historicity with their family members in search of security. When they find someone to care for the sibling, feelings of relief, tranquility, and comfort stand out, reassured in their effort to provide maternal care.

Oh, my everything, my safe haven is her. Oh no, leaving a boy with other families will not do. My mother is my mother. (Mother 2)

Oh I always leave her with someone who will pay attention to her. Then I'll explain to her [daughter]: "Mommy is going to the doctor. Mommy will be back soon." So she always stays there with my sister. (Mother 9)

Because it's my mother who helps with [daughter's name]. Just like when I was hospitalized before I got him [premature], she was the one. Then when she came along and stayed as my escort here in the NICU, it was my sister who stayed with her [daughter]. So it's always the two taking turns. (Mother 8)

The sibling's father's family was cited as secondary support for specific needs, including those of women. The justification always revolved around the existence of relational conflicts between the sibling and people in the home, the presence of another person who demanded close and intense care, and the degree of confidence and security felt by the mother.

My mother-in-law has a daughter with Down syndrome and she has other problems, not just the syndrome. That's a lot of work for my mother-in-law. Then my mother-in-law cannot be taking care of her granddaughter because of her daughter. Because she has to watch over her all the time. (Mother 1)

And he does not get along with my sister-in-law, who is the little girl she [mother-in-law] has. Then he would come home crying. (Mom 2)

Then she [paternal grandmother] said "no, you can be carefree that I stay with him [son] as much as you need." Then as he was already there, I just asked her to stay with him until I got back. Then I came back and picked him up. (Mother 7) 
The men of the family (grandfathers and father) end up being integrated in one-off activities, highlighting the displacement of the child, mainly to ensure going to school. In relation to the father, work and end of the relationship with the mother were the main reported elements that excluded him from being the sibling's main caregiver, but the paternal figure was conceived as the person who supports the one to be listed as the main caretaker.

And my husband, too, works hard, helps when it's possible. (Mother 6)

The father works, and he cannot be caring all day, so I left with my mother. (Mother 10)

Her father works in the market, so he drives her to school and back, because we are not together anymore. But he sees her every day because he drives her to and back from kindergarten. (Mother 8)

\section{Thematic unit: promotion of adaptation to the arrival of the sibling}

Promoting the sibling's adaptation to the baby is a move that mothers perform before birth, when, for example, they ask the firstborn to talk to the intrauterine child in order to promote recognition as a sibling and adapt to the change that is coming.

Since I got pregnant I ask him [sibling] to talk to my belly. I asked him to lie down on my stomach and talk to her [premature]. I've been talking like this to make him less jealous. (Mother 2)

Every time I lay down or show my belly more, because there are times when you will change clothes, he would say, "Mom, there's a baby in your belly, right, Mommy? [name of premature]". Because when I learned I was pregnant, I did the ultrasound, I already knew it was a girl, then I went and chose the name, then I already spoke her name to him. (Mother 3 )

After the premature child's birth, one of the maternal concerns is to tell the sibling about what happened. However, due to the possible hospitalization of the mother in the maternity ward and the premature infant in NICU, they are often physically distant from the sibling. Thus, telephone conversations become the resource used to keep them in touch in some way, as well as for transmission of information and monitoring of how the sibling is reacting to the new situation.

They tell the sibling about their new brother or sister, in those moments, using simple explanations, with a view to understanding. Introducing siblings to each other is the prevailing maternal action to empower both and manage any potential jealousy. To the premature, mothers reinforce the importance of the struggle for their own recovery and of meeting the sibling, and to the sibling they tell about the need for waiting for physical contact and living together, emphasizing that they will be supporters in caring for him.

I already told you that there is a little sister here, that she [daughter] will help change the little baby girl, that she will help me bathe the baby too, that she has to help Mom do things for the one that is here [refers to premature]. By the time I get there I'll show it to her, I'll teach her that she can put on her lap when Mommy is around. You have to learn to live together also because they are sisters. I talk about this on the phone, when I go there too. (Mother 1)

Even for her [premature] I also say that her little brother is looking forward to seeing her. That she should get well quickly so we can leave. I talk to them a lot. (Mother 2)

Another action to contribute to the sibling's adaptation to the arrival of the baby, particularly a preterm baby, is to promote his/ her relations with other young children, to explain/appreciate contributions predicted by the mother as possible to be developed a posteriori by the child in the care of the premature, and to teach to share, working on the sharing of space and attention.

I'm trying, I'll do my best to make them get along, and be happy. Oh these little things that I have to teach. Teach her to share. (Mother 5)

Then every time there was a little baby in the streets I would ask to stop and watch. To show her that she was going to have one just like that at home. [...] I try to show that there is no difference at all, that they will be both treated the same. (Mother 1)

\section{Thematic unit: maternal feelings and coping}

Women feel divided between their children because they need to be physically distant from one when they are with the other. However, they are constantly with both in thought, wondering if they are well and getting the best possible. Experiencing such a situation is a constant challenge to their sense of good parenting and this brings suffering. However, they need to be able to withstand this situation and therefore seek to reassure themselves.

Oh, I'm crazy about life, I like her so much [daughter]. But at the same time, well, I know I need to come, because the one that is here [premature] also needs me. If I could I would bring her along, I would not leave her at all. It's very heart-wrenching to have to leave her [sibling] there and leave that [premature] here. When I am here I keep thinking about what's there. And when I'm there I keep thinking about what's here. At the same time I have to be there and here. We do not ever get well, ever. What can I do?! I need to say it has to be this way. Tell myself, you know, however, I cannot stop thinking about them, always having to away from one. It's crazy and one is driven nuts if one does not calm down. I talk myself into [thinks] calming down. (Mother 1)

Nothing is easy. But God knows better. It is not easy, the little heart is there, and the other here [...]. The problem is that both of them need me, but I think that, for example, if I'm there, I know that [premature] is very well taken care of, of course, because the girls there are angels, they are like an angel. But any time they need to call me, I'm here in the hospital. Like him [sibling] there, he's pretty perfect, being very well taken care of by my mother, there is nothing the matter with him. If only I could be with both of them, that would make me feel better. (Mother 2)

But I kept thinking "then I'm leaving and if he [premature] needs me here to collect some blood or something quickly?! How am I supposed to leave him here? And the one there?" It is hard, it hurts. (Mother 6) 
The mothers of this study sought different ways to alleviate suffering in the face of obstacles encountered from gestation on, with the premature birth and estrangement of the other child. To do so, some lean on the companion's support or the sibling's company to diminish the anguish they experience, and they believe that the solitude brings guilty feelings about their current situation. All of the participants believe that finding the expected support strengthens them to face the circumstances, bringing momentary relief of suffering.

I really get sad.. [...] I go to the room, I get [name of sibling], I go to bed. Sometimes I go out to the street, I go to my children's father to improve, to get well soon. (Mother 4)

Oh, it's in my husband that I find strength, because some days I cannot do it. I avoid being alone, I just do not stay alone at all. Because if I'm alone I'm going to despair. [...] Then my husband goes there, we talk, he stays close to me, heed me. He's talking to me there, it hurts, but it's not all that desperati, gives me some attention. As he talks with me it hurts, but it not that desperation, and anguish recedes. Because every time I'm alone I go into despair, like, one starts worrying too much about everything, then I feel guilty about the situation. (Mother 5 )

In the midst of these experiences, they find in the crying a moment of purification that contributes to their well-being, relieving emotional pain. Care is taken not to let it show to the child, in case they see their mothers' cry they might suffer as well.

Then I cry a lot. I feel better. It all passes. (Mother 4)

If I get alone, it's over. I do not like [daughter's name] seeing me crying because she will not understand. She'll keep asking. So I avoid that. (Mother 5)

When I cry, he [son] cannot see it. Got it? Because if he sees I'm crying, he'll think, "Oh, my mother is crying so I'm going to cry too." (Mother 6)

\section{DISCUSSION}

From mothers' narratives, the study showed how mothers take care of the sibling of a child born preterm, during hospitalization in NICU, conforming to the new rearrangements that such parental activity required. Due to the need to be emotionally and physically close to the premature infant, reflecting the significance of this child being more fragile and exposed to risks, they take care of their other child by using their social support network. Physical estrangement of the children leads to ambiguous feelings in the mother, who weaves reflections aimed at being comforted and conforming to the limits.

Family dynamics is altered and in the process of a new organization, which will be temporary but founds and favors family and maternal coping throughout the period of hospitalization of its new member. These findings related to changes in routine and family dynamics are in line with a study on the development of the maternal role in relation to the child's hospitalization in $\mathrm{NICU}^{(13)}$. Reality becomes, as identified here, giving priority to the premature baby ${ }^{(3,5)}$ and coping with the feeling of abandoning the other child ${ }^{(5)}$.
When considering the family life cycle, transitions resulting from the birth of a child determine changes in the form and use of the social network, in order to support the new demands ${ }^{(1)}$, considering as options the extended family (grandparents, uncles, cousins), friends, partners, neighbors and professionals ${ }^{(14-15)}$.

In view of the need to offer parental-like care to sibling(s) of a premature child hospitalized, the selection of the source of support is based on the axes of closeness, availability of time and care offered ${ }^{(16)}$, usually culminating in calling grandparents, father and/or some elder child ${ }^{(3)}$. Although mentioned in the literature as a supporter, the mention of father was minor in this study, limited to occasional caring actions, a fact that reinforces the need for transformations of health practices accordingly. It is necessary to rethink the model for insertion of the premature child's father ${ }^{(17)}$, but also siblings and other family members in the hospitalization process, including the mother herself.

The literature on family and maternal support during a child's stay in NICU highlights that the social support structure is almost solitary ${ }^{(18)}$ and portrays professionals' reception and support in matters related to family and maternal reorganization in this context as incipient ${ }^{(18-19)}$. It is imperative that NICU teams extend their care focus beyond solving the child's medical problems and consider partnership and interest in family issues ${ }^{(20)}$.

Nurses have greater and different opportunities for contact with mothers throughout the child's stay in NICU, when recognition and appreciation of the human responses presented by mothers is essential. It is up to nurses to seek the development of skills and knowledge that encompass interventions directed to such needs. They need to expand their clinic with a view to specific interventions, especially in the direction of the sufferings experienced by these women-mothers, especially those related to guilty feelings from moving away from one of the children and/ or not reaching the idealized care offer to both children ${ }^{(21)}$.

Indeed, the need to transform health and nursing practices is more evidenced by the fact that mothers may mention supportive actions on the part of health professionals, reflecting the probable caring philosophy that supports them in their practices. It is worth noting that, in relation to maternal coping and reflections about the problem, the professional who accompanies the woman in coping with this situation can help her visualize her social network in order to find support ${ }^{(22)}$, an intervention highlighted in a classic book of family nursing ${ }^{(23)}$, nevertheless little present in nursing practice in Brazil. In addition to helping to expand the social network, the professional should also be the provider of support and dialogue, in order to work and face the lived reality from within, which is a remarkable step in this process of coping and daily adaptations in the everyday challenges of this experience ${ }^{(24)}$.

Preterm birth can be considered a traumatic event and a source of anxiety for siblings, due to a drop in predictability ${ }^{(7)}$. The interpretation of simulations and games performed by siblings aged between 20 months and 6 years shows that children's feelings and behaviors are influenced by anxiety, parental actions and absences. Interpretations covered themes such as temporary loss of belonging or objects, new identity in the family, attempts to internalize the new baby and ambivalence of feelings. The hospitalization of the premature child awakens blame for the situation, a sense of abandonment, need for physical and affective 
contact with parents, and fantasies about human character and personality ${ }^{(7)}$.

Another study also points out that, from a maternal point of view, the birth of the preterm infant brings changes in the child's routine due to mother's having to be away in NICU, culminating in a feeling of worry, jealousy and anxiety ${ }^{(3)}$. Welcoming this child has the benefits of clarifying the need for hospitalization of the preterm newborn and the presence of the mother in the hospital, reducing fantasies and reducing negative feelings, as well as emotional adaptation to the situation, insertion of premature infants into the family context and the beginning of the development of fraternity ${ }^{(6)}$.

The importance of welcoming was reinforced in an American intervention study, which also showed the possibility of including siblings in this environment. The activities, which made children feel special and parents grateful, included social worker support, through the delivery of coloring and/or writing materials about their own life or experience in NICU, depending on their age; support of nurses in simulation with dolls, incubators and intravenous devices; support from volunteer parents who made contact with parents during children's activities or photographed those moments; library for reading next to the premature baby or in the family room; support of a trained volunteer who, three to four times a week, watched over the siblings while parents were with the premature child; and psychological support in case of mourning ${ }^{(23)}$. In this study, promotion of adaptation and fraternity was signified by mothers as a form of care for the premature child, culminating in interactional actions of the gestation, when they asked for a conversation between children, the hospitalization period, when there was a telephone contact to inform about the situation and relieve the absence. In another study ${ }^{(3)}$, mothers chose to show photographs, and those that found it pertinent and did not feel blocked by institutional norms, took the son for a visitation to the NICU.

Despite recommendations regarding the inclusion of siblings as focus of care, as well as their insertion into the NICUs ${ }^{(6,25)}$, the reality is still flawed. A study involving nine European countries and 175 neonatal intensive care units with at least 50 admissions per month of very low birth weight infants indicated that, despite improvements in family access policies, there are still barriers, especially in southern Europe (France, Spain and Italy). As for visitation by siblings, $75 \%$ of the institutions allow that practice, however, mostly under parental supervision, with other options only by acceptance or with consent of professionals ${ }^{(26)}$. In South America, 15 of the 52 neonatal intensive care units, analyzed through a questionnaire answered by nurses, do not allow sibling visits. Cultural changes are necessary in order to achieve respect for family rights, since there is a strong belief that their access to NICU and the premature child only impair nursing care. It should be noted that there was no analysis regarding Brazil, since the questionnaires sent were not returned ${ }^{(27)}$.

\section{Limitations of the study}

As a limitation of the study, it is pointed out that it was developed in a single municipality, encompassing the socio-cultural specificity and health care network relative to it. In this sense, it is suggested that its replication to other realities also be effective as research investment, due to the impossibility of generalizations.
Another point is the fact of having only mothers as participants. Thus, in order to amplify evidence that would direct the sibling as welcome in the same reality of this study, further research is recommended that listen to other social actors who are part of this scenario, such as the very sibling, NICU professionals and hospital managers.

Also, in future studies, aspects that touch on the phenomena mentioned in this study can be explored, for example, particularities of specific ethnic groups, interprofessionality and empowerment of the mother throughout child' NICU stay, among others.

\section{Contributions to the nursing area}

This study made it possible to highlight relevant factors to broaden the perspective that supports health care in NICU, especially as an invitation to nursing professionals to welcome the family and siblings who experience the birth of a premature child, in its integrality and intersubjectivity, not as a caring action empty of meanings, but as a humanistic attitudinal differential that reinforces the need to reformulate health care, based on the precepts of rights, humanization and integrality. Although these precepts are easily verbalized, in order to be effective in practice they require humanistic and ethical values, which are incipiently explored in health and nursing education, in their different levels and modalities. In this way, it also raises reflections about nursing education, values and discussions mobilized in it.

\section{FINAL CONSIDERATIONS}

From the analysis of the data, it is reinforced that maternal care to the sibling of the premature child hospitalized is developed under a physical distance from him, given the woman's understanding of having to stay close to the hospitalized child, due to risks and fragilities. Such action awakens guilty and abandonment feelings, with a desire to be with them both.

In dependence on comfort for themselves, mothers use their social networks as a source of support in the care of the sibling, with considerations regarding their actions in terms of meeting children's needs, especially emotional ones, in addition to the development of internal dialogues related to be doing their best to provide care for all of their children.

Promoting child adaptation to the role of being a sibling is another strategy found by the mothers. They seek forms of affective interaction between child and sibling, still in pregnancy, supported by the idea that the bonds won between siblings in this period are important for development of family and fraternal relationships.

The study gives visibility to the maternal problem of being a mother of other children, in addition to hospitalization in NICU, and suggests a lack of perception and intentionality of professional reception, with the need for transformations to reach a comprehensive and human care. Thus, globally, there remains some reflections on whether the opening of NICU to siblings would not be a way to attenuate maternal suffering and simultaneously welcome the family in their life cycle adaptations, given the hospitalization of a family member in this environment. Reflections also remain on the consideration and value that health and nursing practices have been contributing to the construction and effectiveness of 
maternity, formation and protection of bonds and attachment. Interactions with mothers of children in NICU show incipiences in the consideration of the various social roles she occupies and, in a way, are denying rights to her and her children.

\section{FUNDING}

Masters Scholarship - Coordenação de Aperfeiçoamento de Pessoal de Nível Superior (Capes).

\section{REFERENCES}

1. Carter B, McGoldrick M. As mudanças no ciclo de vida familiar: uma estrutura para a terapia familiar. In: As mudanças no ciclo de vida familiar: uma estrutura para a terapia familiar. $2^{\text {a }}$ ed. Porto Alegre: Artes Médicas; 2001. p. 206-22.

2. McGoldrick M, Shibusawa T. O ciclo vital familiar. In: Walsh F, organizadora. Processos normativos da família: diversidade e complexidade. $4^{a}$ ed. Porto Alegre: Artmed. 2016. p. 375-398.

3. Mousquer PN, Leão LCS, Kepler DF, Piccinini CA, Lopes RCS. Mom, where is the baby? Repercussions of the premature birth of a sibling Estud Psicol. 2014;31(4):527-37. doi: 10.1590/0103-166X2014000400007

4. Ministério da Saúde (BR). Departamento de Informática do SUS (DATASUS). Declaração de nascidos vivos [Internet]. Brasília; 2014 [cited 2017 July 4]. Available from: http://tabnet.datasus.gov.br/cgi/tabcgi.exe?sinasc/cnv/nvuf.def

5. Antunes BS, Paula CC, Padoin SMM, Trojahn TC, Rodrigues AP, Tronco CS. Hospitalization of newborns in Neonatal Unit: the meaning for the mother. Rev Rene. 2014;15(5):796-803. doi: 10.15253/2175-6783.2014000500009

6. Ministério da Saúde (BR). Atenção humanizada ao recém-nascido de baixo peso: método canguru [Internet]. Brasília; 2017 [cited 2018 Mar 7]. Available from: http://bvsms.saude.gov.br/bvs/publicacoes/atencao_humanizada_metodo_canguru_manual_3ed.pdf

7. Camhi C. Siblings of premature babies: thinking about their experience. Infant Obs. 2005;8(3):209-33. doi: 10.1080/13698030500375776

8. Minayo MCS. Qualitative analysis: theory, steps and reliability. Ciênc Saúde Colet. 2012;17(3):621-6. doi: 10.1590/S1413-81232012000300007

9. Charon JM. Symbolic interactionism: an introduction, an interpretation, an integration. 10th ed. London: Pearson; 2009.

10. Instituto Brasileiro de Geografia e Estatística (IBGE). Brasil em Síntese. Uberaba, Minas Gerais [Internet]. Rio de Janeiro: IBGE; 2017 [cited 2017 July 13]. Available from: https://cidades.ibge.gov.br/v4/brasil/mg/uberaba/panorama

11. Lieblich A, Tuval-Mashiach R, Zilber T. Narrative research: reading, analysis and interpretation. Thousand Oaks: Sage; 1998.

12. Castellanos MEP. The narrative in qualitative research in health. Ciênc Saúde Colet. 2014;19(4):1065-76. doi: $10.1590 / 1413-81232014194.12052013$

13. Lamy ZC, Morsch DS, Deslandes SF, Fernandes RT, Rocha LJLF, Lamy Filho F, et al. The formation of the maternal role from experience of hospitalization in the Neonatal Intensive Care Unit in two models of care. Rev Pesq Saúde [Internet] 2011 [cited 2018 Mar 6];12(1):14-21. Available from: http://www.periodicoseletronicos.ufma.br/index.php/revistahuufma/article/view/919

14. Leão DM, Silveira A, Rosa EO, Balk RS, Souza NS, Torres OM. Family home care to the child with chronic diseases: an integrative review. J Nurs UFPE On Line. 2014;8(suppl 1):2445-54. doi: 10.5205/reuol.5927-50900-1-SM.0807suppl201432

15. Nishimoto CLJ, Duarte ED. Family organization for the care of children with chronic conditions, discharged from the neonatal intensive care unit. Texto Contexto Enferm. 2014;23(2):318-27. doi: 10.1590/0104-07072014001330013

16. Silveira AO, Bernardes RC, Wernet M, Pontes TB, Silva AAO. Family's social support network and the promotion of child development. REFACS. 2016;4(1):6-16. doi: 10.18554/refacs.v4i1.1528

17. Soares RLSF, Christoffel MM, Rodrigues EC, Machado MED, Cunha AL. The meanings of caring for pre-term children in the vision of male parents. Texto Contexto Enferm. 2016;25(4):e1680015. doi: 10.1590/0104-07072016001680015

18. Custodio N, Marski BSL, Abreu FCP, Mello DF, Wernet M. Interactions between health personnel and mothers of preterms: influences on maternal care. Rev Enferm UERJ. 2016;24(1):e11659. doi: 10.12957/reuerj.2016.11659

19. Facio BC, Marski BSL, Higarashi IH, Misko MD, Silveira AO, Wernet M. (Un)receptiveness in interactions with professionals: experiences of parents of children with retinopathy of prematurity. Rev Esc Enferm USP. 2016;50(6):913-21. doi: 10.1590/s0080-623420160000700006

20. Hall SL, Hynan MT, Phillips R, Lassen S, Craig JW, Goyer E, et al. The neonatal intensive parenting unit: an introduction. J Perinatol. 2017;37(12):1259-64. doi: 10.1038/jp.2017.108

21. Carmona EV, Vale IN, Ohara CVS, Abrão ACFV. Diagnóstico de enfermagem "conflito no desempenho do papel de mãe" em mães de recémnascidos hospitalizados. Rev Latino-Am Enfermagem. 2013;21(2):571-8. doi: 10.1590/S0104-11692013000200014

22. Araújo YB, Reichert APS, Vasconcelos MGL, Collet N. Fragilidade da rede social de famílias de crianças com doença crônica. Rev Bras Enferm. 2013;66(5):675-81. doi: 10.1590/S0034-71672013000500006

23. Wright LM, Leahey M. Enfermeiras e famílias: um guia para a avaliação e intervenção na família. 5a ed. São Paulo: Roca; 2012.

24. Oliveira K, Veronez M, Higarashi IH, Corrêa DAM. Vivências de familiares no processo de nascimento e internação de seus filhos em UTI neonatal. Esc Anna Nery. 2013;17(1):46-53. doi: 10.1590/S1414-81452013000100007 
25. Levick J, Quinn M, Holder A, Nyberg A, Beaumont E, Munch S. Support for siblings of NICU patients: an interdisciplinary approach. Soc Work Health Care. 2010;49(10):919-33. doi: 10.1080/00981389.2010.511054

26. Greisen G, Mirante N, Haumont H, Pierrat V, Pallás-Alonso CR, Warren I, et al. Parents, siblings and grandparents in the Neonatal Intensive Care Unit: a survey of policies in eight European countries. Acta Pædiatr. 2009;98(11):1744-50. doi: 10.1111/j.1651-2227.2009.01439.x

27. Bueno MTM, Quiroga A, Rodríguez S, Sola A. Family access to Neonatal Intensive Care Units in Latin America: a reality to improve. An Pediatr (Barc.). 2016;85(2):95-110. doi: 10.1016/j.anpede.2015.07.039 